\title{
Relationship between the production of prostaglandins and progesterone by luteinizing human granulosa cells
}

\author{
R C Fowkes ${ }^{1,2}$, C Chandras ${ }^{1,2}$, E C Chin ${ }^{2}$, S Okolo ${ }^{3}$, \\ D R E Abayasekara ${ }^{2}$ and A E Michael ${ }^{1,2}$
} ${ }^{1}$ Department of Biochemistry and Molecular Biology, Royal Free and University College Medical School (Royal Free Campus), University College London,
Rowland Hill Street, London NW3 2PF, UK
${ }^{2}$ Department of Veterinary Basic Sciences, Royal Veterinary College, Royal College Street, London NW1 OTU, UK
${ }^{3}$ Academic Department of Obstetrics and Gynaecology, Royal Free Hospital, Pond Street, London NW3 2QG, UK
R C Fowkes is now at Department of Endocrinology, St Bartholomews and the Royal London School of Medicine \& Dentistry, Molecular Endocrinology
Lab 14, First Floor, Dominion House, 59 Bartholomew Close, London EC1A 7BE, UK
(Requests for offprints should be addressed to A E Michael, Department of Biochemistry and Molecular Biology, RF\&UCMS (Royal Free Campus), UCL,
Rowland Hill Street, London NW3 2PF, UK; Email: a.michael@rfc.ucl.ac.uk

\begin{abstract}
Luteinizing granulosa cells synthesize high concentrations of progesterone, prostaglandin $(\mathrm{PG}) \mathrm{E}_{2}$ and $\mathrm{PGF}_{2 \alpha}$. The objective of this study was to explore the relationship between prostaglandin and progesterone output from human granulosa cells as they undergo functional luteinization in culture. Granulosa cells were partially purified from ovarian follicular aspirates and cultured at a density of $10^{5}$ cells $/ \mathrm{ml}$ in serum-supplemented DMEM:Ham's $\mathrm{F}_{12}$ medium for 0,1 or 2 days. Cells were then switched to serum-free medium for $24 \mathrm{~h}$ before measuring hormone concentrations in this spent medium by specific radioimmunoassays. Over the first 3 days in culture, $\mathrm{PGF}_{2 \alpha}$ and $\mathrm{PGE}_{2}$ production declined progressively by up to $82 \pm 3 \%$ coincident with a $55 \pm 11 \%$ increase in progesterone
\end{abstract}

output. In subsequent experiments, cells were treated for $24 \mathrm{~h}$ on the second day of culture with either 0.01 to $10 \mu \mathrm{M}$ meclofenamic acid or with $10 \mu \mathrm{M}$ and $100 \mu \mathrm{M}$ aminoglutethimide. Meclofenamic acid inhibited synthesis of $\mathrm{PGF}_{2 \alpha}$ and $\mathrm{PGE}_{2}$ by up to $70 \pm 9 \%$ and $64 \pm 7 \%$ respectively without affecting progesterone output. Likewise, $100 \mu \mathrm{M}$ aminoglutethimide inhibited progesterone production by $62 \pm 6 \%$ without affecting concentrations of either $\mathrm{PGF}_{2 \alpha}$ or $\mathrm{PGE}_{2}$. We have concluded that the progressive decline in prostaglandin production and the rise in progesterone output from luteinizing human granulosa cells occur independently of each other.

Journal of Endocrinology (2001) 171, 455-462

\section{Introduction}

Following the preovulatory gonadotrophin surge, induction of the expression of cyclo-oxygenase/prostaglandin $\mathrm{H}$ synthase (PGHS)-2 confers on luteinizing granulosa cells the capacity to synthesize high concentrations of prostaglandins (LeMaire et al. 1975, Espey 1980, Ainsworth et al. 1984, Richards 1994, Sirois 1994, Narko et al. 1997, Richards et al. 1998). Increased generation of these inflammatory mediators has been implicated in follicular rupture and ovulation of the mature oocyte (Grinwich et al. 1972, Espey 1980, Richardson 1986, Munalulu et al. 1987). However, the significance of locally synthesized prostaglandins in the paracrine/autocrine control of ovarian steroidogenesis has yet to be established. A number of studies in a wide range of species have demonstrated that treatment of luteinized cells with exogenous prostaglandin $(\mathrm{PG}) \mathrm{E}_{2}$ stimulates progesterone biosynthesis whereas $\mathrm{PGF}_{2 \alpha}$ and its analogues have generally been reported to inhibit luteal steroidogenesis (reviewed in Richardson 1986, Michael et al. 1993, 1994, Olofsson \& Leung 1994). Based on these documented effects, we hypothesized that locally synthesized prostaglandins may act in an autocrine/paracrine manner to dictate the level of progesterone synthesis in luteinizing granulosa cells. Moreover, since progesterone has been inversely correlated with prostaglandin synthesis in the corpus luteum (CL) (Patek \& Watson 1976, Rothchild 1981), we also speculated that increasing output of progesterone from luteinizing granulosa cells may suppress $\mathrm{PGF}_{2 \alpha}$ and/or $\mathrm{PGE}_{2}$ production from such cells. Hence, the objective of the present study was to investigate the relationship between the production of both $\mathrm{PGF}_{2 \alpha}$ and $\mathrm{PGE}_{2}$ and the output of progesterone from human granulosa cells as they luteinize in vitro. To examine the role of endogenous prostaglandins in regulating progesterone synthesis, cells were treated with meclofenamic acid, a pharmacological inhibitor of prostaglandin biosynthesis (Boctor et al. 1986, 
Zelinski-Wooten et al. 1990). Similarly, in order to establish the role of progesterone in the paracrine control of prostaglandin production, endogenous progesterone synthesis was suppressed by treatment of cells with aminoglutethimide, a known inhibitor of steroidogenic cytochrome P450 enzymes (Wilroy et al. 1968, Touitou et al. 1973, El-Hefnawy \& Huhtaniemi 1998, Peluso \& Pappalardo 1999).

\section{Materials and Methods}

\section{Materials}

Phosphate-buffered saline (PBS), Earle's balanced salt solution (EBSS), 1:1 (v/v) Dulbecco's modified Eagle's medium:Ham's $\mathrm{F}_{12}$ (DMEM: $\mathrm{F}_{12}$ ) medium, foetal calf serum (FCS), antibiotics and L-glutamine were all purchased from Life Technologies Ltd (Uxbridge, Middx, UK). Organic solvents, which were of HPLC grade, were supplied by Merck (Poole, Dorset, UK). Percoll and all other compounds were purchased from Sigma Chemical Co. (Poole, Dorset, UK). Antiserum for the immunoassay of progesterone was obtained from the Central Veterinary Laboratory (Weybridge, Surrey, UK) while antibodies to $\mathrm{PGE}_{2}$ and $\mathrm{PGF}_{2 \alpha}$ were generously donated by Drs R W Kelly and N L Poyser respectively (University of Edinburgh, Edinburgh, UK).

\section{Patient samples}

Ovarian follicular aspirates were collected from women undergoing assisted conception at the Hallam Medical Centre, Harley Street, London, UK with informed patient consent (in accordance with the Declaration of Helsinki) and with the approval of the local ethics committee. Pituitary down-regulation was achieved by the subcutaneous administration of a gonadotrophin-releasing hormone $(\mathrm{GnRH})$ analogue (Suprecur; Shire Pharmaceuticals, Andover, Hants, UK; $500 \mu \mathrm{g} /$ day from day 2 of the cycle for 10-21 days). Administration of the GnRH analogue was then continued in conjunction with purified urinary human menopausal gonadotrophin (Menogon; Ferring Pharmaceuticals, Feltham, Middx, UK; 2-4 ampoules daily for 10-14 days) followed by a single intramuscular injection of human chorionic gonadotrophin (Profasi; Serono, Welwyn Garden City, Herts, UK; 5000$10000 \mathrm{IU}) 36 \mathrm{~h}$ prior to oocyte collection. Follicles were subsequently aspirated under local anaesthesia by the transvaginal route.

\section{Isolation of human granulosa-lutein cells}

Ovarian follicular aspirates were kept at room temperature and were sent to the Royal Free Campus of the Royal Free and University College Medical School within $3 \mathrm{~h}$ of collection. On arrival, ovarian cells and contaminating blood cells were precipitated from the supernatant follicular fluid and follicular flushing medium (EBSS) by centrifugation at $250 \mathrm{~g}$ for $10 \mathrm{~min}$ at $4{ }^{\circ} \mathrm{C}$. After resuspension in PBS, human granulosa cells were partially purified on 60\% (v/v) Percoll as described previously (Webley et al. 1988). The number of granulosa cells obtained from a given patient using this protocol ranged between 1.4 and $7 \cdot 6 \times 10^{6}$ cells. Cell viabilities, which were assessed by the exclusion of trypan blue dye, were routinely in excess of $85 \%$ and did not change significantly over the course of any of the experiments described below.

Culture of human granulosa-lutein cells: collection of spent culture medium for hormone assays

In all experiments, cells were seeded into sterile 24-well cell culture plates at a density of $1 \times 10^{5}$ viable cells $/ \mathrm{ml}$ culture medium with a volume of $1 \mathrm{ml}$ medium per well. In cases where prostaglandin and progesterone production were to be estimated over the first $24 \mathrm{~h}$ of culture, cells were seeded in DMEM:Ham's $\mathrm{F}_{12}$ medium supplemented with $0.01 \%(\mathrm{w} / \mathrm{v})$ bovine serum albumin $(\mathrm{BSA})$, penicillin (87 $000 \mathrm{IU} / \mathrm{l})$, streptomycin $(87 \mathrm{mg} / \mathrm{l})$ and L-glutamine $(2 \mathrm{mM})$. In all other experiments, cells were prepared and seeded in the same cell culture medium supplemented with $10 \%(\mathrm{v} / \mathrm{v})$ FCS in place of the BSA. Cells were subsequently incubated at $37{ }^{\circ} \mathrm{C}$ in a humidified atmosphere of $5 \%(\mathrm{v} / \mathrm{v}) \mathrm{CO}_{2}$ in air.

For daily measurements of progesterone and prostaglandin concentrations, cells were incubated for 0,1 or 2 days in serum-supplemented medium before being switched to serum-free medium for a period of $24 \mathrm{~h}$ (designated as day 1,2 or 3 of cell culture respectively). To remove any residual serum, wells were each rinsed twice with 200$300 \mu \mathrm{l}$ warmed serum-free medium and this washing medium discarded before adding $1 \mathrm{ml}$ fresh serum-free medium to each well. At the end of the 24-h collection period, the spent serum-free medium was transferred to micro test tubes and stored frozen at $-20{ }^{\circ} \mathrm{C}$ pending progesterone, $\mathrm{PGE}_{2}$ and $\mathrm{PGF}_{2 \alpha}$ assays. (Analysis by light microscopy confirmed that this spent culture medium did not contain detached granulosa-lutein cells.)

\section{Effects of meclofenamic acid on prostaglandin and progesterone production}

Cells were cultured overnight in serum-supplemented medium to allow the cells to attach to the wells of the cell culture plate. On the second day of culture, cells were rinsed with serum-free medium and then incubated for a further $24 \mathrm{~h}$ in serum-free medium containing $0,0 \cdot 01$, $0 \cdot 1,1$ or $10 \mu \mathrm{M}$ meclofenamic acid. (These concentrations were selected based on an $\mathrm{IC}_{50}$ for the inhibition of PGHS activity by meclofenamic acid of $0.6 \mu \mathrm{M}$ (Boctor et al. 1986).) At the end of the $24-\mathrm{h}$ incubation period, medium 
was collected and stored at $-20{ }^{\circ} \mathrm{C}$ pending assay of the prostaglandin and progesterone concentrations. Meclofenamic acid was prepared to a stock concentration of $100 \mathrm{mM}$ in dimethylsulphoxide, the final concentration of which was adjusted in all wells to $0 \cdot 1 \%(\mathrm{v} / \mathrm{v})$.

\section{Effects of aminoglutethimide on prostaglandin and progesterone production}

After an overnight culture in serum-supplemented medium, cells were rinsed with serum-free medium and then incubated for a further $24 \mathrm{~h}$ in serum-free medium containing aminoglutethimide at concentrations of 0,10 or $100 \mu \mathrm{M}$. (These concentrations were selected on the basis of previous reports demonstrating inhibition of adrenal and gonadal steroidogenesis at aminoglutethimide concentrations of 86-500 $\mu \mathrm{M}$ (Wilroy et al. 1968, Touitou et al. 1973, El-Hefnawy \& Huhtaniemi 1998, Peluso \& Pappalardo 1999).) At the end of the 24-h incubation period, medium was collected and stored at $-20{ }^{\circ} \mathrm{C}$ pending assay of the prostaglandin and progesterone concentrations. A stock concentration of $100 \mathrm{mM}$ aminoglutethimide was prepared in chloroform. The final concentration of this organic solvent was adjusted in all wells to $0 \cdot 1 \%(\mathrm{v} / \mathrm{v})$.

\section{Hormone assays}

All hormone concentrations were measured in $100 \mu \mathrm{l}$ aliquots of serum-free culture medium using radioimmunoassay (RIA) protocols that have been described previously (Kelly et al. 1986, Poyser 1987, Pallikaros et al. 1995). For each RIA, samples were assayed at dilutions of up to $1 / 1000$ as required to ensure that the hormone measurements were made within the linear range of the relevant standard curve. In our hands, the progesterone RIA was found to have a working range of $0 \cdot 4-15 \mathrm{nM}$ with intra- and interassay coefficients of variation $(\mathrm{CV})$ of $8 \%$ and $14 \%$ respectively. The working ranges for the $\mathrm{PGF}_{2 \alpha}$ and $\mathrm{PGE}_{2}$ assays were equal to $1 \cdot 6-28 \mathrm{nM}$ and $0 \cdot 1-7 \mathrm{nM}$ respectively. The intra- and interassay $\mathrm{CV}$ values were less than $8 \%$ and $11 \%$ respectively for both prostaglandin assays. The antibody used in the RIA for $\mathrm{PGE}_{2}$ showed a cross-reactivity of $0.47 \%$ for $\mathrm{PGF}_{2 \alpha}$ at $50 \%$ binding and the antibody used in the $\mathrm{PGF}_{2 \alpha}$ RIA exhibited $0 \cdot 17 \%$ cross-reactivity with $\mathrm{PGE}_{2}$.

\section{Statistics}

All data were subjected to statistical analysis using GraphPad Prism 2 software (San Diego, CA, USA). The time-dependent changes in prostaglandin and progesterone output from cultured cells were evaluated in the first instance by one-way ANOVA with repeated measures (across individual experiments) followed by Dunnet's multiple comparison considering hormone concentrations on the first day of culture as control values. All concentration-dependent effects of a given treatment on the concentrations of progesterone and/or prostaglandins were similarly assessed by one-way ANOVA with repeated measures (for cells from a given patient) followed, as appropriate, by Dunnet's test. Probabilities of less than 0.05 were accepted as statistically significant in all analyses. All experiments were repeated three to twelve times with triplicate wells for each condition in each experiment. A given experiment featured granulosa-lutein cells from one patient only and, for each patient, cells were pooled from all aspirated follicles.

\section{Results}

Daily patterns of prostaglandin and progesterone production

Over the first 3 days of culture, concentrations of both $\mathrm{PGF}_{2 \alpha}$ and $\mathrm{PGE}_{2}$ declined progressively by $82 \pm 3 \%$ and $75 \pm 8 \%$ respectively (means \pm S.E. of nine independent experiments; $P<0.05$ relative to corresponding prostaglandin concentrations on the first day of culture; Fig. 1A and $\mathrm{B})$. Over this same culture period, the concentration of progesterone increased by $55 \pm 11 \%$ (mean \pm s.E. of twelve independent experiments) relative to the progesterone concentrations on the first day of culture (Fig. 1C). The progressive rise in progesterone production over the first 3 days in culture is in agreement with several previous studies into the endocrinology of human granulosa cells as they undergo functional luteinization in vitro (e.g. McNatty et al. 1979, Polan et al. 1984, Hurwitz et al. 1987, Tapanainen et al. 1987, Wickings et al. 1989, Michael \& Webley 1991, Brzezinski et al. 1992).

\section{Effects of meclofenamic acid on prostaglandin and progesterone} production

Incubation for $24 \mathrm{~h}$ with meclofenamic acid resulted in a concentration-dependent suppression of $\mathrm{PGF}_{2 \alpha}$ production at concentrations of meclofenamic acid $\geq 10 \mathrm{nM}$ (Fig. $2 \mathrm{~A})$. At the maximum tested concentration of $10 \mu \mathrm{M}$, meclofenamic acid suppressed $\mathrm{PGF}_{2 \alpha}$ production by $70 \pm 10 \%$ (mean \pm s.e. of five independent experiments; $P<0 \cdot 01)$. At concentrations of $1 \mu \mathrm{M}$ and $10 \mu \mathrm{M}$, meclofenamic acid also inhibited $\mathrm{PGE}_{2}$ accumulation by $73 \pm 6 \%$ and $71 \pm 8 \%$ respectively (means \pm s.e. of five independent experiments; $P<0 \cdot 05$; Fig. 2B). However, progesterone synthesis was unaffected by meclofenamic acid at any of the tested concentrations (Fig. 2C).

Effects of aminoglutethimide on prostaglandin and progesterone production

Incubation for $24 \mathrm{~h}$ with $100 \mu \mathrm{M}$ aminoglutethimide suppressed progesterone production by $64 \pm 7 \%$ (mean \pm s.E. 
( A)

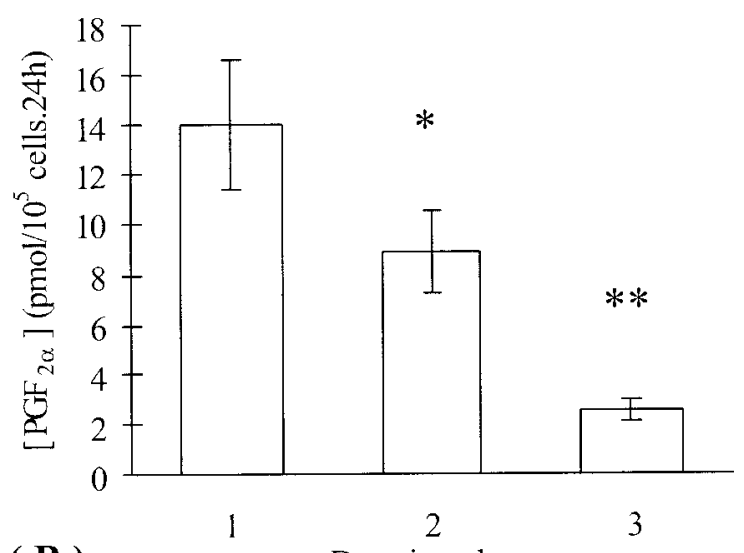

( B )

Days in culture

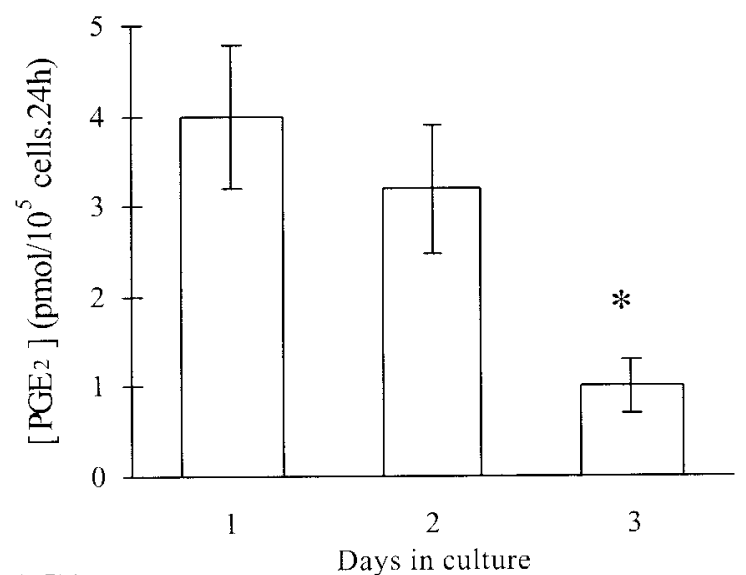

( C)

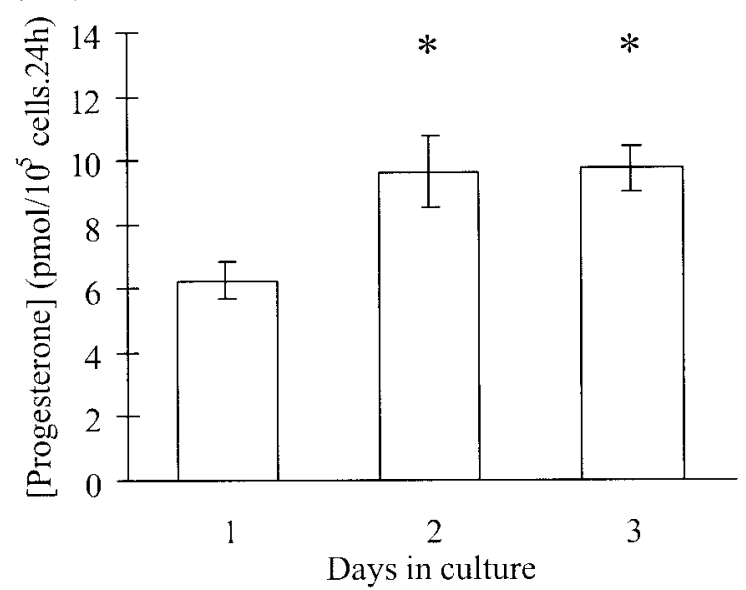

Figure 1 Hormone concentrations in spent culture medium collected over 24-h intervals during continuous culture of human granulosa-lutein cells. Values are the means \pm S.E. for nine $((A)$ $\mathrm{PGF}_{2 \alpha}$ and $\left.(\mathrm{B}) \mathrm{PGE}_{2}\right)$ or $12((\mathrm{C})$ progesterone) independent experiments with triplicate determinations in each experiment. ${ }^{*} P<0 \cdot 05,{ }^{*} P<0 \cdot 01$ relative to concentrations of the appropriate hormone on day 1 of culture.
(A)

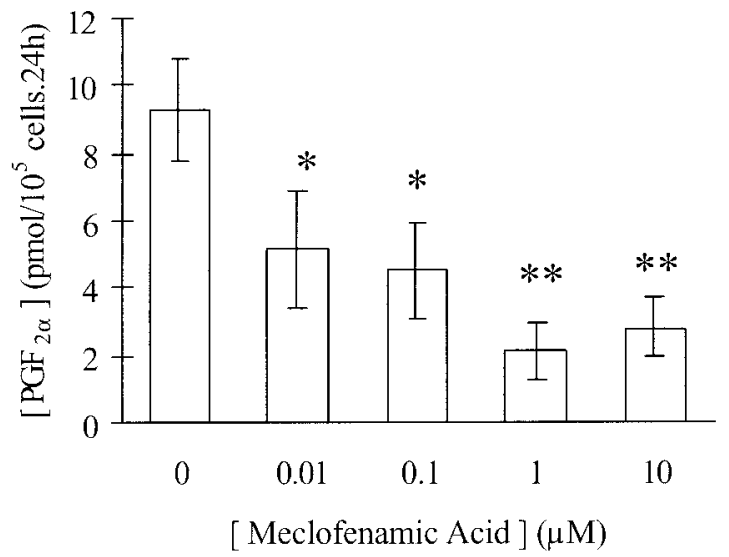

( B )

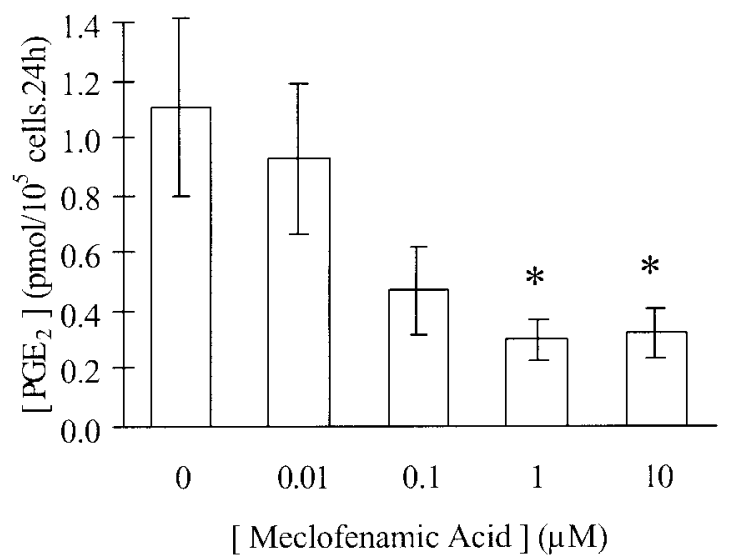

(C)

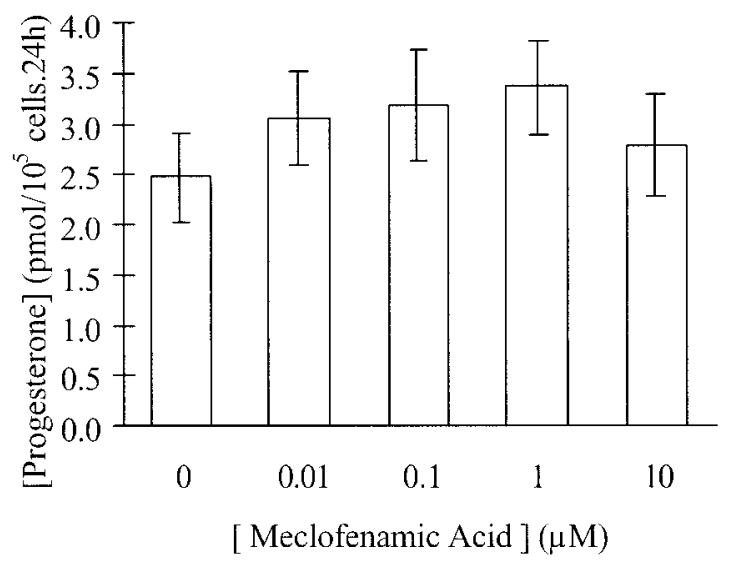

Figure 2 Concentration-dependent effects of meclofenamic acid on the accumulation of (A) $\mathrm{PGF}_{2 \alpha^{\prime}}$ (B) $\mathrm{PGE}_{2}$ and (C) progesterone in spent medium from cultured human granulosa-lutein cells. All values are the means \pm S.E. for five independent experiments with triplicate determinations in each experiment. ${ }^{*} P<0 \cdot 05,{ }^{* *} P<0 \cdot 01$ versus control. 
(A)

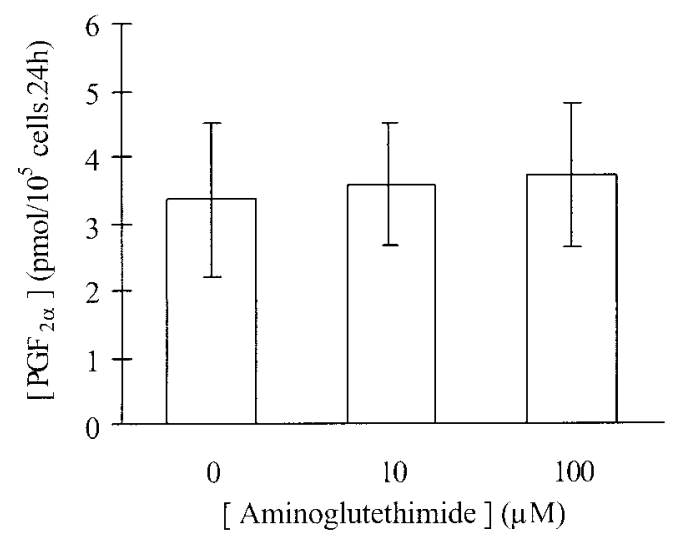

(B)

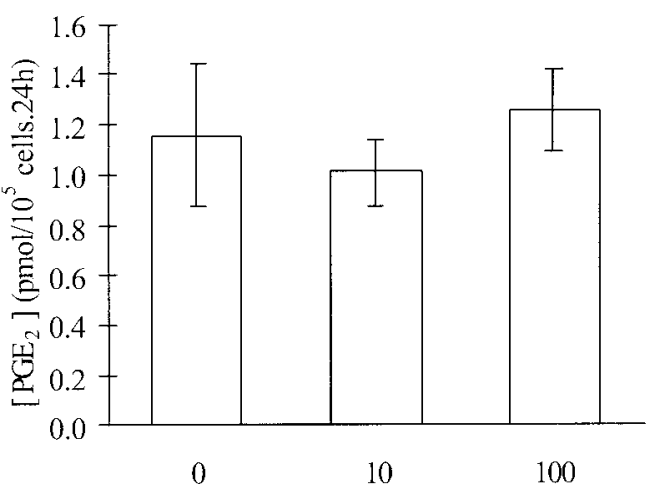

[ Aminoglutethimide ] $(\mu \mathrm{M})$

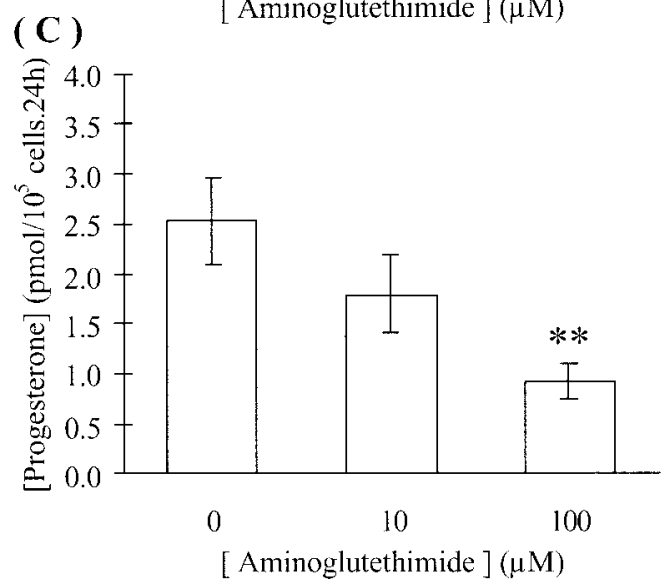

Figure 3 Concentration-dependent effects of aminoglutethimide on the accumulation of (A) $\mathrm{PGF}_{2 \alpha^{\prime}}$ (B) $\mathrm{PGE}_{2}$ and $(\mathrm{C})$ progesterone in spent medium from cultured human granulosa-lutein cells. Values are the means \pm S.E. for three $\left(\mathrm{PGF}_{2 \alpha}\right)$ or five $\left(\mathrm{PGE}_{2}\right.$ and progesterone) independent experiments with triplicate determinations in each experiment. ${ }^{* *} P<0 \cdot 01$ versus control.

of five independent experiments; $P<0 \cdot 01$; Fig. 3C) with no significant effect at $10 \mu \mathrm{M}$ aminoglutethimide. However, treatment with an effective concentration of this cytochrome $\mathrm{P} 450$ inhibitor had no significant effect on the production of either $\mathrm{PGF}_{2 \alpha}$ (Fig. 3A) or $\mathrm{PGE}_{2}$ (Fig. 3B).

\section{Discussion}

The present study reports coincident changes in the output of $\mathrm{PGF}_{2 \alpha}, \mathrm{PGE}_{2}$ and progesterone by human granulosalutein cells over the first 3 days of culture. The observation that declines in prostaglandin concentrations coincide with the rise in progesterone raises three possibilities. First, in view of the established inhibitory effect of $\mathrm{PGF}_{2 \alpha}$ on ovarian progesterone synthesis (reviewed in Richardson 1986, Auletta \& Flint 1988, Michael et al. 1994, Olofsson \& Leung 1994), the marked decline in $\mathrm{PGF}_{2 \alpha}$ production may facilitate the rise in progesterone synthesis by the luteinizing cells. Secondly, the increase in progesterone concentrations over the first 3 days in culture may suppress $\mathrm{PGF}_{2 \alpha}$ and $\mathrm{PGE}_{2}$ output. Finally, there may be no causal relationship between the pattern of production of progesterone and the assayed prostaglandins as the cells luteinize in vitro. As discussed below, this report presents novel data which demonstrate that the decline in prostaglandin output and progressive rise in progesterone secretion from luteinizing human granulosa cells occur independently of each other and are not causally interdependent.

In order for endogenous synthesis of prostaglandins to determine progesterone production from luteinizing cells, the concentrations of those prostaglandins would need to approximate to the $K_{\mathrm{d}}$ values for the various subtypes of $\mathrm{PGF}_{2 \alpha}$ and $\mathrm{PGE}_{2}$ receptors (FP and EP receptors respectively). On day 1 of culture this was indeed the case; the mean $\mathrm{PGF}_{2 \alpha}$ concentration of $14 \cdot 0 \pm 2 \cdot 6 \mathrm{nM}$ (i.e. $14 \cdot 0 \pm 2 \cdot 6 \mathrm{pmol} / 10^{5}$ cells $\times 10^{5}$ cells $/ \mathrm{ml}$ ) approximates to the $K_{\mathrm{d}}$ of $13 \mathrm{nM}$ for $\left.{ }^{3} \mathrm{H}\right] \mathrm{PGF}_{2 \alpha}$ binding to the human CL (Rao et al. 1977) and exceeds the $K_{\mathrm{d}}$ for the cloned human FP receptor of $8.3 \pm 2.5 \mathrm{nM}$ (Lake et al. 1994). The situation for the receptor-mediated response to $\mathrm{PGE}_{2}$ is complicated by the fact that, at present, there are four cloned subtypes of the EP receptor, designated EP1 to $\mathrm{EP} 4$, with $K_{\mathrm{d}}$ values that range from $1 \mathrm{nM}$ for the human EP1 receptor to $11 \mathrm{nM}$ for the human EP2 receptor (Coleman et al. 1994). Certainly, at the concentration of $4 \cdot 0 \pm 0 \cdot 8 \mathrm{nM}$ (measured on the first day of cell culture), $\mathrm{PGE}_{2}$ produced by the luteinizing granulosa cells would be capable of binding to the EP2 and EP4 receptor subtypes which (through their ability to activate the cyclic adenosine- $3^{\prime}, 5^{\prime}$-monophosphate-protein kinase A pathway) have the capacity to stimulate ovarian steroidogenesis.

To test whether the progressive decline in $\mathrm{PGF}_{2 \alpha}$ output could account for the concomitant increase in progesterone production, cells were incubated with a range of concentrations of meclofenamic acid. This non-steroidal, anti-inflammatory agent inhibited prostaglandin output by up to $82 \pm 3 \%$ when used in the high 
$\mathrm{nM}$ to low $\mu \mathrm{M}$ concentration range, consistent with prior reports of the potency of meclofenamic acid as an inhibitor of PGHS activity in other cell types (Boctor et al. 1986, Zelinski-Wooten et al. 1990). However, in view of the novel observation that meclofenamic acid did not significantly affect progesterone output at concentrations of up to $10 \mu \mathrm{M}$, it seems unlikely that the endogenous production of prostaglandins in luteinizing human granulosa cells dictates the ability of such cells to synthesize progesterone.

In making the above observations, we note that the synthesis of $\mathrm{PGF}_{2 \alpha}$ appeared to be more sensitive to inhibition by meclofenamic acid than did the production of $\mathrm{PGE}_{2}$, even though the maximum degree of inhibition of both prostaglandins was comparable at the upper concentration of $10 \mu \mathrm{M}$ meclofenamic acid. At concentrations of $0 \cdot 01$ and $0 \cdot 1 \mu \mathrm{M}$, which are below the published $\mathrm{IC}_{50}$ for inhibition of cyclo-oxygenase/PGHS activity, meclofenamic acid significantly inhibited $\mathrm{PGF}_{2 \alpha}$ accumulation without significantly affecting $\mathrm{PGE}_{2}$ synthesis. This discrepancy is hard to explain if one assumes that meclofenamic acid acts solely by inhibiting arachidonic acid metabolism at the level of the cyclo-oxygenase/ lipoxygenase enzymes, and may indicate preferential inhibition of $\mathrm{PGF}_{2 \alpha}$ synthesis by low concentrations of meclofenamic acid. This could reflect direct effects of meclofenamic acid on PGF synthase activity and/or conversion of $\mathrm{PGE}_{2}$ to $\mathrm{PGF}_{2 \alpha}$, catalysed by PGE-9ketoreductase. Alternatively, decreased intracellular concentrations of $\mathrm{PGH}_{2}$ following inhibition of PGHS activity may have a greater impact on the generation of $\mathrm{PGF}_{2 \alpha}$ than $\mathrm{PGE}_{2}$ due to the relative affinities of PGF and PGE synthase for the decreased amount of prostaglandin substrate.

A consideration when evaluating changes in prostaglandin production is the potential of the cells of interest to oxidise prostaglandins to their 13,14-dihydro-15-keto metabolites. In the present study, the possible metabolism of $\mathrm{PGF}_{2 \alpha}$ and $\mathrm{PGE}_{2}$ by 15-hydroxyprostaglandin dehydrogenase (PGDH) did not appear to be relevant since we have previously obtained two lines of evidence to indicate that human granulosa-lutein cells do not express significant PGDH activity, irrespective of the experimental treatments to which the cells have been exposed (A E Michael \& D R E Abayasekara; unpublished data). First, while spent culture medium does contain 13,14-dihydro5-keto-PGF ${ }_{2 \alpha}$ (PGFM) immunoreactivity, the apparent concentrations of PGFM in spent culture medium are typically less than $5 \%$ of the concentrations of $\mathrm{PGF}_{2 \alpha}$ and so can simply be attributed to cross-reaction of $\mathrm{PGF}_{2 \alpha}$ in the PGFM RIA. Moreover, when human granulosalutein cells are incubated with $\left[{ }^{3} \mathrm{H}\right] \mathrm{PGF}_{2 \alpha}$ for up to $24 \mathrm{~h}$ prior to the resolution of $\left[{ }^{3} \mathrm{H}\right]$-labelled metabolites by high performance liquid chromatography, we have been unable to identify any $\left[{ }^{3} \mathrm{H}\right] \mathrm{PGFM}$. Hence, the suppression of $\mathrm{PGF}_{2 \alpha}$ and $\mathrm{PGE}_{2}$ secretion from cells treated with meclofenamic acid and indomethacin reflects inhibition of prostaglandin biosynthesis (at the level of PGHS) rather than stimulation of PG metabolism by PGDH.

To test whether the progressive rise in cellular progesterone output could account for the decline in $\mathrm{PGF}_{2 \alpha}$ and $\mathrm{PGE}_{2}$ concentrations, cells were incubated with a range of concentrations of aminoglutethimide. This toxin has been used in a number of studies, including studies of human granulosa-lutein cells, to inhibit cytochrome P450 cholesterol side-chain cleavage and other cytochrome P450 members of the steroidogenic pathway. The concentration of aminoglutethimide required to significantly suppress progesterone secretion $(100 \mu \mathrm{M})$ was consistent with that required to inhibit steroid biosynthesis in previous studies of ovarian and adrenal cells (Wilroy et al. 1968, Touitou et al. 1973, El-Hefnawy \& Huhtaniemi 1998, Peluso \& Pappalardo 1999). Despite decreasing progesterone production in the present study by $62 \pm 6 \%, 100 \mu \mathrm{M}$ aminoglutethimide had no significant effect on the concentration of either prostaglandin measured. On the basis of this novel finding, we propose that the decline in $\mathrm{PGF}_{2 \alpha}$ and $\mathrm{PGE}_{2}$ concentrations in spent medium as human granulosa cells luteinize in vitro is unlikely to be a consequence of the increasing progesterone production.

In experimental designs of the type employed in this study, it is usual to test whether the effects of the pharmacological inhibitors are specific and/or reversible by replacing the hormone that has been suppressed by the test compound. In those experiments that featured meclofenamic acid, it would have been usual to have treated the cells with $\mathrm{PGE}_{2}$ to $\mathrm{PGF}_{2 \alpha}$, having suppressed endogenous prostaglandin synthesis, to establish whether any effects on progesterone production could be reversed. However, this element of the study was not justified since treatment of cells with meclofenamic acid had no significant effect on steroidogenesis in the first instance. Similarly, it was not necessary to treat cells exposed to $100 \mu \mathrm{M}$ aminoglutethimide with exogenous progesterone since this cytochrome P450 inhibitor had no significant effect on concentrations of the measured prostaglandins.

The cell culture system used in this study was selected as a readily available functional approximation to the luteinizing granulosa cells of the newly formed CL. However, extrapolations between our in vitro observations and those biochemical changes that occur as human granulosa cells luteinize in vivo must be made with extreme caution for three major reasons. First, the granulosa cells employed in this and in similar studies have been exposed to pharmacological doses of gonadotrophins prior to isolation and culture. At this stage, it is not possible to comment on the precise biochemical impact of this endocrine history, but it would seem reasonable to assume, based on prior publications, that this might influence the in vitro output of both prostaglandins and steroid hormones. Secondly, the cell preparations obtained after centrifugation on $60 \%(\mathrm{v} / \mathrm{v})$ Percoll contain a variety of cell types other than granulosa cells, of which most appear to 
be ovarian macrophages, fibroblasts and erythrocytes. The contaminating erythrocytes are of limited significance since they do not adhere (and so are removed) during the course of cell culture, in addition to which they can be removed easily by gentle osmotic lysis. In our laboratories, we routinely assess the proportion of viable cells that are granulosa cells by assessing $3 \beta$-hydroxysteroid dehydrogenase (3ßHSD) activity using an immunocytochemical test. When incubated with a $3 \beta$-hydroxy-, $\Delta^{5}$-androgen substrate (androst-5-ene-3 $\beta, 17 \beta$-diol), excess $\mathrm{NAD}^{+}$and nitroblue tetrazolium, $82 \pm 7 \%$ (mean \pm s.E. of eight independent measurements) of all viable cells stain positive for $3 \beta \mathrm{HSD}$ activity as reflected in the deposition of the insoluble reduced formazan salt. Hence we are confident that, in the present study, ovarian leukocytes plus fibroblasts would have accounted for less than $20 \%$ of the cultured cells. Clearly, any contaminating leukocytes might be expected to influence prostaglandin production from the granulosa cells through the local production of proinflammatory cytokines. However, we would argue that the newly forming human CL, which is a very highly vascularized gland, contains a large number of nonsteroidogenic cells, particularly macrophages, which might similarly influence prostaglandin and progesterone output by luteinizing granulosa cells in vivo. The third and final factor that limits extrapolation between the data reported herein and the biochemical changes that occur as granulosa cells luteinize in vivo is our inability to accurately model the hormonal and cellular environment of the granulosa cells in vitro. In the newly forming CL, granulosa cells would be exposed to relatively high concentrations of luteinizing hormone (and, to a lesser extent, folliclestimulating hormone) which we made no attempt to approximate since we had decided to examine changes in prostaglandin and progesterone output under true basal conditions. Moreover, in the immature CL, there appears to be a functional dialogue between the luteinizing granulosa and luteinizing theca cells which cannot be reproduced in vitro since it is not possible to isolate appreciable numbers of human theca cells from follicular aspirates. Taken together, these three major limitations on the interpretation of our data restrict the clinical significance of our data, but do not detract from the validity of our observations under the stated conditions.

Despite the caveats defined above, the model of cultured human granulosa-lutein cells is a widely used in vitro system which does appear to mirror many of the biochemical changes that occur when granulosa cells undergo functional luteinization in vivo. We are therefore confident that the biochemical changes reported herein are likely to occur as cells differentiate in the early luteal phase, subject to modulation by gonadotrophins, luteinizing theca cells, and paracrine agents produced by non-steroidogenic cells in the immature CL.

In summary, inhibition of endogenous prostaglandin synthesis by cultured human granulosa-lutein cells had no significant effect on their progesterone output, and suppression of progesterone synthesis had no impact on the $\mathrm{PGF}_{2 \alpha}$ or $\mathrm{PGE}_{2}$ concentrations in spent culture medium. We conclude, therefore, that the dynamic changes in the output of $\mathrm{PGF}_{2 \alpha}, \mathrm{PGE}_{2}$ and progesterone from luteinizing human granulosa cells over the first 3 days of culture probably occur independently of each other.

\section{Acknowledgements}

We wish to acknowledge the staff at the Hallam Medical Centre for the collection of ovarian cells, and to thank Ms $\mathrm{T} D \mathrm{C}$ Collins and $\mathrm{Mr} \mathrm{S}$ Kharim for their technical assistance in performing these studies. This work was supported by project grant 049831 from the Wellcome Trust.

\section{References}

Ainsworth L, Tsang BK, Marcus GJ \& Downey BR 1984 Prostaglandin production by dispersed granulosa and theca interna cells from porcine preovulatory follicles. Biology of Reproduction 31 115-121.

Auletta FJ \& Flint APF 1988 Mechanisms controlling corpus luteum function in sheep, cows, non human primates, and women especially in relation to the time of luteolysis. Endocrine Reviews 9 88-105.

Boctor AM, Eickholt M \& Pugsley TA 1986 Meclofenamate sodium is an inhibitor of both the 5-lipoxygenase and cyclo-oxygenase pathways of the arachidonic acid cascade in vitro. Prostaglandins and Leukotrienes in Medicine 23 229-238.

Brzezinski A, Fibich T, Cohen M, Schenker JG \& Laufer N 1992 Effects of melatonin on progesterone production by human granulosa lutein cells in culture. Fertility and Sterility 58 526-529.

Coleman RA, Smith WL \& Narumiya S 1994 VIII. International Union of Pharmacology classification of prostanoid receptors: properties, distribution, and structure of the receptors and their subtypes. Pharmacological Reviews 46 206-229.

El-Hefnawy T \& Huhtaniemi I 1998 Progesterone can participate in down regulation of the luteinizing hormone receptor gene expression and function in cultured murine Leydig cells. Molecular and Cellular Endocrinology 137 127-138.

Espey LL 1980 Ovulation as an inflammatory reaction - a hypothesis. Biology of Reproduction 22 73-106.

Grinwich DL, Kennedy TG \& Armstrong DT 1972 Dissociation of ovulatory and steroidogenic actions of luteinizing hormone with indomethacin: an inhibitor of prostaglandin biosynthesis. Prostaglandins 1 89-96.

Hurwitz A, Laufer N, Keshet I, Rabinowitz R, Lewin A, Palti Z \& Schenker JG 1987 The effect of insulin on progesterone production and cellular growth in long-term cultures of human granulosalutein cells. Fertility and Sterility 48 791-795.

Kelly RW, Healy DL, Cameron MJ, Cameron IT \& Baird DT 1986 The stimulation of prostaglandin production by two antiprogesterone steroids in human endometrial cells. Journal of Clinical Endocrinology and Metabolism 62 1116-1123.

Lake S, Goullberg H, Wahlqvist J, Siogren AM, Kinhult A, Lind P, Hellstrom-Linhahl E \& Stjernschantz J 1994 Cloning of the rat and human prostaglandin $\mathrm{F}_{2 \alpha}$ receptors and the expression of the rat prostaglandin $\mathrm{F}_{2 \alpha}$ receptor. FEBS Letters 355 317-325.

LeMaire WJ, Leidner R \& Marsh JM 1975 Pre and postovulatory changes in the concentration of prostaglandins in the rat Graafian follicles. Prostaglandins 3 367-376. 
McNatty KP, Makris A, DeGrazia C, Osathanondh R \& Ryan KJ 1979 The production of progesterone, androgens, and estrogens by granulosa cells, thecal tissue, and stromal tissue from human ovaries in vitro. Journal of Clinical Endocrinology and Metabolism 49 687-699.

Michael AE \& Webley GE 1991 Prior exposure to gonadotrophins prevents the subsequent antigonadotrophic actions of cloprostenol by a cyclic AMP-dependent mechanism in cultured human granulosa cells. Journal of Endocrinology 131 319-325.

Michael AE, Abayasekara DRE \& Webley GE 1993 The luteotrophic actions of prostaglandin $\mathrm{E}_{2}$ and $\mathrm{F}_{2 \alpha}$ are differentially mediated via cyclic AMP and protein kinase C. Journal of Endocrinology 138 291-298.

Michael AE, Abayasekara DRE \& Webley GE 1994 Cellular mechanisms of luteolysis. Molecular and Cellular Endocrinology 99 R1-R9.

Munalulu BM, Hillier K \& Peddie MJ 1987 Effect of human chorionic gonadotrophin and indomethacin on ovulation, steroidogenesis and prostaglandin synthesis in preovulatory follicles of PMSG-primed immature rats. Journal of Reproduction and Fertility $80229-234$

Narko K, Ritvos O \& Ristimaki A 1997 Induction of cyclooxygenase-2 and prostaglandin $\mathrm{F} 2 \alpha$ receptor expression by interleukin $-1 \beta$ in cultured human granulosa-luteal cells. Endocrinology 138 3638-3644.

Olofsson J \& Leung PCK 1994 Autocrine/paracrine role of prostaglandins in corpus luteum function. Molecular and Cellular Endocrinology 100 87-91.

Pallikaros Z, Schulster D, Baldwin SA, Helliwell RJA, Michael AE \& Cooke BA 1995 Characterization of site-directed antibodies to the LH receptor in functionally active gonadal cells and their differential effects on LH-stimulated signal transduction in Leydig tumor (MA-10) cells. Molecular and Cellular Endocrinology 114 57-68.

Patek CE \& Watson J 1976 Prostaglandin F and progesterone secretion by porcine endometrium and corpus luteum in vitro. Prostaglandins 12 97-111.

Peluso JJ \& Pappalardo A 1999 Progesterone maintains large rat granulosa cell viability indirectly by stimulating small granulosa cells to synthesize basic fibroblast growth factor. Biology of Reproduction $60290-296$

Polan ML, Laufer N, Dlugi AM, Tarlatzis BC, Haseltine FP, DeCherney AH \& Behrman HR 1984 Human chorionic gonadotropin and prolactin modulation of early luteal function and luteinizing hormone receptor-binding activity in cultured human granulosa-luteal cells. Journal of Clinical Endocrinology and Metabolism 59 773-779.

Poyser NL 1987 Effects of various factors on prostaglandin synthesis by the guinea-pig uterus. Journal of Reproduction and Fertility $\mathbf{8 1}$ 269-276.

Rao ChV, Griffin LP \& Carman FR Jr 1977 Prostaglandin F F $_{2 \alpha}$ binding sites in human corpora lutea. Journal of Clinical Endocrinology and Metabolism 44 1032-1037.

Richards JS 1994 Hormonal control of gene expression in the ovary. Endocrine Reviews 15 725-751.

Richards JS, Russell DL, Robker RL, Dajee M \& Alliston TN 1998 Molecular mechanisms of ovulation and luteinization. Molecular and Cellular Endocrinology 145 47-54.

Richardson MC 1986 Hormonal control of ovarian luteal cells. Oxford Reviews in Reproductive Biology 8 321-378.

Rothchild I 1981 The regulation of the mammalian corpus luteum. Recent Prooress in Hormone Research 37 183-298.

Sirois J 1994 Induction of prostaglandin endoperoxide synthase- 2 by human chorionic gonadotrophin in bovine preovulatory follicles in vivo. Endocrinology 135 841-848.

Tapanainen J, Leinonen PJ, Tapanainen P, Yamamoto M \& Jaffe RB 1987 Regulation of human granulosa-luteal cell progesterone production and proliferation by gonadotrophins and growth factors. Fertility and Sterility 48 576-580.

Touitou Y, Legrand JC \& Desgrez P 1973 Adrenocortical steroidogenesis and aminoglutethimide. II. Cytochemical and ultrastructural changes. Practical and theoretical values. Biomedicine 18 272-278.

Webley GE, Luck MR \& Hearn JP 1988 Stimulation of progesterone secretion by cultured human granulosa cells with melatonin and catecholamines. Journal of Reproduction and Fertility 84 669-677.

Wickings EJ, Hillier SG \& Riechert LE Jr 1989 Gonadotrophic control of steroidogenesis in human granulosa-lutein cells. Journal of Reproduction and Fertility 76 677-684.

Wilroy RS Jr, Camacho AM, Trouy RL \& Hagen AA 1968 Inhibition of adrenal cortical secretion by amino-glutethimide in dogs. Endocrinology 83 56-60.

Zelinski-Wooten MB, Sargent EL, Molskness TA \& Stouffer RL 1990 Disparate effects of the prostaglandin synthesis inhibitors, meclofenamate, and flurbiprofen on monkey luteal tissue in vitro. Endocrinology 126 1380-1387.

Received 24 May 2001

Accepted 13 August 2001 